A RCHIWA, BIBLIOTEKI

I MUZEA KOŚCIELNE 109 (2018)

https://doi.org/10.31743/abmk.2018.109.18

DOMINIK ZAMIATAŁA CMF* - WARSZAWA

\title{
WSPÓŁPRACA WYDZIAŁÓW WYZNANIOWYCH PAŃSTW BLOKU WSCHODNIEGO (WSPÓLNE NARADY)
}

Państwa Europy Środkowej, które znalazły się w wyniku postanowień wielkiej trójki w Jałcie pod dominacją Związku Radzieckiego i jego ideologii komunistycznej, zostały zobligowane do różnego rodzaju współdziałania i sojuszy w ramach bloku wschodniego. Podjęły one współpracę pod egidą Kremla na poziomie przywódców partii komunistycznych i innych jej przedstawicieli oraz służb specjalnych. Współpraca ta objęła również dziedzinę gospodarczą, dla której w 1949 r. utworzono Radę Wzajemnej Wspólnoty Gospodarczej (RWPG), jako socjalistyczną odpowiedź na zachodni Plan Marshalla oraz sprawy wojskowe w postaci powołanego w $1955 \mathrm{r}$. Układu Warszawskiego ${ }^{1}$. W ich wyniku doszło do pewnej unifikacji politycznej, ideologicznej, wojskowej, gospodarczej, czy służb specjalnych w ramach bloku wschodniego. Kwestia współpracy i wymiany doświadczeń między poszczególnymi krajami komunistycznymi nie ominęła polityki wyznaniowej. Zmieniająca się linia polityczna wobec religii i Kościołów po 1956 r. spowodowała, że wśród decydentów i urzędników organów wyznaniowych z poszczególnych krajów zrodziła się potrzeba wspólnych spotkań celem wymiany informacji, doświadczeń oraz koordynacji działań w tej dziedzinie. Ogólny rozwój sytuacji międzynarodowej wymagał od nich ustalania wspólnych wystąpień taktycznych, jedności ideowej i politycznej w kwestiach wyznaniowych. W zamyśle inicjatorów tej współpracy była także wzajemna pomoc w osiąganiu lepszych wyników pracy Urzędów ds. Wyznań krajów socjalistycznych, w realizacji polityki

* Ks. Dominik Zamiatała CMF - dr hab. historii; prof. w Zakładzie Studiów Europejskich; Uniwersytet Kardynała Stefana Wyszyńskiego; e-mail: dominikzm@interia.pl

${ }^{1}$ E. Skobelski, Polityka PRL wobec państw socjalistycznych w latach 1956-1970. Wspótpraca-napięcia-konflikty, Poznań 2010, s. 185-238; J. Zając, R. Zięba, Polska w stosunkach międzynarodowych 1945-1989, Toruń 2005. S. 11-12; M. Dmowski, Organizacja Układu Warszawskiego 1955-1980. LRB, CSRS, NRD, PRL, SRR, WRL, ZSRR. Dokumenty i materiaty, Warszawa 1981; S. Parzymies, Stosunki międzynarodowe w Europie 1945-2009, Warszawa 2009, s. 80-82; P. Madajczyk, Dyplomacja polska w latach sześćdziesiatych, w: Historia dyplomacji polskiej, t.VI: 1944/451989, red. W. Materski, W. Michowicz, Warszawa 2010, s. 589-591. 
wyznaniowej wyznaczanych im przez własne partie rządzące. Tym działaniom miały służyć przede wszystkim organizowane spotkania, konferencje przedstawicieli urzędów do spraw wyznań krajów socjalistycznych. Potrzeba i pogłębienie współpracy pomiędzy krajami socjalistycznymi w „,dziedzinie kościelno-politycznej” - jak uzasadniali przedstawiciele peerelowskiego UdsW - wypływała „ze zwiększonej aktywności wszystkich Kościołów, ich światowych central”2. W tych naradach oprócz właściwych urzędników odpowiedzialnych za pion wyznaniowy brali udział także partyjni funkcjonariusze odpowiedzialni za pion ideologiczny w Komitetach Centralnych partii komunistycznych ${ }^{3}$. Organizowano je także z powodu pojawiających się nowych okoliczności, które obligowały do wspólnych decyzji. Skład delegacji poszczególnych krajów, liczył zazwyczaj po trzy osoby.

Pierwsza wspólna konferencja odbyła się w 1956 r. w Pradze, następna w Berlinie (1960 r. $)^{4}$, rok później w Karlowych Warach ${ }^{5}$, kolejna w Budapeszcie (1962 r.), w Berlinie (1964 r.). Sytuacja religijna i aktywizacja Kościołów, a zwłaszcza Kościoła katolickiego, spowodowała potrzebę organizowania takich narad w kolejnych latach. Wartym zauważenia jest fakt, że w pierwszym okresie poszczególne państwa nie kwapiły się do organizowania tych konferencji u siebie.

$\mathrm{Na}$ tych wspólnych spotkaniach starano się podejmować bieżące i interesujące wszystkie urzędy zagadnienia polityki wyznaniowej w poszczególnych państwach socjalistycznych, jak i na arenie międzynarodowej ${ }^{6}$. Rozpoczynał je z reguły wcześniej ustalony i wyznaczony z konkretnej delegacji referat wprowadzający. Do tych referatów podchodzono z bardzo dużą uwagą, skoro często $\mathrm{w}$ ich przygotowanie angażowano najważniejsze czynniki polityczne i rządowe $\mathrm{w}$ tych krajach. Zgodnie z postanowieniami konferencji budapeszteńskiej, program kolejnych konferencji był tak ustalany, aby poddawane kwestie pod dyskusję stanowiły logiczny ciąg obrad poprzednich i mogły być uwzględnione nowe propozycje ${ }^{7}$.

W latach 60.70. i 80. XX w. najczęściej omawianymi zagadnieniami wspólnych narad były sprawy dotyczące Watykanu, Chrześcijańskiego Konferencji Pokojowej $^{8}$, Berlińskiej Konferencji Katolików, czy Światowej Rady Kościołów.

${ }^{2}$ AAN, UdsW, sygn. 136/10, Pismo Kierownika sekretariatu do spraw kościelnych Kareła Hruzy do Aleksander Skarżyński Dyrektor Urzędu do Spraw Wyznań w Warszawie, z dnia 12.10.1967 r., k. 50-51.

${ }^{3}$ Tamże.

${ }^{4}$ Narodní Archiv v Praze (dalej: NAP), sygn. 47, Zapráva z cìekevné politického jednání, které se konalo od 11-15 rijna 1960 v Berlínê, b.p.

${ }^{5}$ NAP, MK-SPLC, Přehled mezístátních jednani v létech 1961-1968, k 12.

${ }^{6}$ AAN, UdsW, sygn. 136/10, Pismo Kierownika sekretariatu do spraw kościelnych Kareła Hruzy do Aleksander Skarżyński Dyrektor Urzędu do Spraw Wyznań w Warszawie, z dnia 12.10.1967 r., k. 50-51.

${ }^{7}$ AAN, UdsW, sygn.136/9, Protokół z konferencji przedstawicieli urzędów wyznaniowych krajów socjalistycznych Warszawa 25-29 wrzesień 1967 r., k. 1-2

${ }^{8}$ Chrześcijańska Konferencja Pokoju z siedzibą w Pradze była organizacją międzynarodową o szerokim zasięgu kontaktów. Zajmowała się światową polityką pokojową i popierała pokojową politykę krajów socjalistycznych. W organizowanych przez nią spotkaniach brali udział przedstawiciele prawie wszystkich krajów świata, za wyjątkiem Chin Ludowych i Tajwanu, Indonezji i Au- 
W kwestii watykańskiej starano się wypracować wspólne stanowisko i jedną generalną linię postępowania wobec Kościoła katolickiego.

Na spotkaniu w Karlowych Warach w 1961 r. wypracowano wytyczne dotyczące Chrześcijańskiej Konferencji Pokojowej (ChKP). Ustalono m.in. następujące zasady działalności tego ruchu:

oddziaływać na wszystkich chrześcijan w duchu powszechnego rozbrojenia, likwidacji kolonializmu, pokojowego rozwiązywania spornych problemów; działalność ChKP rozwijać w takim kierunku, aby wyrósł z niej ruch ogólnoświatowy, jednoczący wszystkich chrześcijan, grupy i jednostki wypowiadające się za pokojem światowym.

Planowano poprzez tę organizację pozyskać większą liczbę zwolenników z krajów kapitalistycznych, zwłaszcza ze Skandynawii oraz Azji, Afryki i Ameryki łacińskiej, a szczególnie znanych osób z kręgów naukowych, artystycznych i młodzieżowych oraz poszerzyć wpływy w międzynarodowych organizacjach politycznych, związkach kobiet, organizacjach chrześcijańskich i wspieranie w kręgach chrześcijańskich propagowanie idei pokoju w duchu sowieckim ${ }^{9}$. Jednocześnie zamierzano

nie dopuścić do tego, aby ChKP stała się ruchem zamkniętym, lecz żeby stała się ruchem otwartym dla wszystkich postępowych elementów, a jednocześnie zapobiegać powstaniu mniemania, że jest to jakaś wschodnia ekumenia ${ }^{10}$.

Kolejne wspólne spotkanie pionów wyznaniowych państw socjalistycznych (PRL, Czechosłowacji, NRD, Węgier, Rumuni, Bułgarii i ZSRR) zorganizowano w Budapeszcie w dniach 25-30 kwietnia 1962 r. ${ }^{11}$ Obrady skoncentrowano na zagadnieniach zawartych w referatach wprowadzających: Problemy wspólnej walki o pokój Kościołów i działaczy kościelnych z krajów socjalistycznych oraz kontakty ze Światowa Rada Kościołów (referat wygłosił przedstawiciel ZSRR), oraz Cel

stralii. Pod koniec lat 60. objęła zasięgiem swojego działania wiele krajów Ameryki Południowej, Azji i Afryki, a także niektóre chrześcijańskie środowiska protestanckie Stanów Zjednoczonych Ameryki. Inicjatywa jej powstania zrodziła się w roku 1958 w Czechosłowacji. Pierwsze ogólnoświatowe Zgromadzenie Pokoju, na którym wybrano władze Konferencji odbyło się w roku 1961, drugie w 1964 r., trzecie w 1969 r. W skład władz Konferencji wchodził międzynarodowy Komitet Wykonawczy i Rada Konsultatywna licząca ponad 100 osób. Posiedzenia odbywały się raz w roku. Konferencją kierował międzynarodowy Sekretariat w którym dominowały w tym okresie przedstawiciele z Czechosłowacji. Na czele Konferencji w latach 60. stał pastor Józef Hromadka. Ważną rolę w Konferencji odgrywali przedstawiciele Rosyjskiej Cerkwii Prawosławnej z Metropolitą Nikodemem na czele, oraz 20. przedstawicieli Kościoła Ewangelickiego z RFN. Z Polski w jej pracach brali udział przedstawiciele Kościołów zrzeszonych w Radzie Ekumenicznej. Od 1963 r. do tej organizacji przystąpiło Chrześcijańskie Stowarzyszenie Społeczne. Członkiem Rady Konsultatywnej był od roku 1964 Poseł J. Makowski. AAN, UdsW, sygn. 127/82, notatka informacyjna, k.14-16.

${ }^{9}$ AAN, UdsW, sygn.136/9, Protokół z konferencji przedstawicieli urzędów wyznaniowych krajów socjalistycznych Warszawa 25-29 wrzesień 1967 r., k. 11

${ }^{10}$ AAN, UdsW, sygn.136/9, Protokół z konferencji przedstawicieli urzędów wyznaniowych krajów socjalistycznych Warszawa 25-29 wrzesień 1967 r., k. 12

${ }^{11}$ AAN, UdsW, 133/3, Program, k. 1; 20-23; NAP, sygn. 47, Zapráva a prübehu mezinárodních porad zástupcu státních uřadu pro vêci cíkevní v Budapesti, b.p. 
i praktyczne zadania Praskiej Chrześcijańskiej Konferencji Pokojowej (referat wygłosił przedstawiciel Czechosłowacji) ${ }^{12}$ oraz Aktualna sytuacja $w$ Watykanie (przedstawił go Tadeusz Żabiński z UdsW) ${ }^{13}$. Dodatkowo każda delegacja przedstawiła wszystkim zebranym informacje o polityce kościelnej w swoim kraju ${ }^{14}$. Na tym zebraniu podjęto również szeroką dyskusję nad odbywanym w Watykanie Soborem. W jej konkluzji postanowiono śledzić działania Kościoła katolickiego tak w trakcje soboru, jak i po jego zakończeniu oraz opracować nową linię postępowania wobec Watykanu ${ }^{15}$. Dokonano także podsumowania trzyletniej działalności Chrześcijańskiej Konferencji Pokoju w Pradze. W toku wymiany różnych ocen i poglądów na jej temat, zwrócono delegacji czechosłowackiej uwagę, aby ta organizacja nie stała się organizacją zamkniętą dla osób z innych krajów socjalistycznych ${ }^{16}$.

Następna wspólna narada przedstawicieli państwowych urzędów do spraw wyznań państw socjalistycznych odbyła się w Berlinie, w dniach 25-30 kwietnia 1964 r. Została zwołana z inicjatywny Czechosłowacji. Na początku 1964 r. - jak relacjonuje urzędnik UdsW - „okazało się konieczne spotkanie dotyczące ustaleń związanych z przygotowaniami do II Ogólnochrześcijańskiego Zgromadzenia Pokojowego w Pradze, które planowano na czerwiec-lipiec 1964 r. oraz spraw III sesji Soboru Watykańskiego (rozpoczęła się 8 września 1964 r.)”.

Spotkanie odbyło się w stolicy NRD, ponieważ inne kraje nie wykazywały inicjatywy zorganizowania jej u siebie ${ }^{17}$. W tej konferencji wzięli udział przedstawiciele urzędów do spraw wyznań i KC partii z ZSRR, CSRS, NRD, Węgier, Bułgarii i PRL. Nie było delegacji rumuńskiej, mimo jej zaproszenia ${ }^{18}$.

Narada skoncentrowała się zgodnie z wcześniejszą zapowiedzią wokół rozwoju i perspektyw Chrześcijańskiej Konferencji Pokojowej oraz przygotowania i przeprowadzenia II Chrześcijańskiej Konferencji Pokojowej w czerwcu 1964 r. w Pradze. Następnie poszczególne delegacje przedstawiły, co stało się już tradycją, informacje dotyczące Kościoła katolickiego w swoich krajach oraz polityce wobec Watykanu. Podjęto również w trakcie tego spotkania konsultacje między

${ }^{12}$ Zadanie i cele tej organizacji były opracowane na najwyższym szczeblu KC KPZR i konsultowane $\mathrm{z}$ innymi KC partii komunistycznych bloku wschodniego. Głównym celem tej organizacji było oddziaływanie na chrześcijan w sprawie pokoju, rozbrojenia, współistnienia w duchu socjalizmu marksistowsko-leninowskim. Miała być też ruchem o zasięgu ogólnoświatowym, jednoczącym ludzi, organizacje, Kościoły. AAN, UdsW, sygn. 136/2, Szczegółowe sprawozdanie z pobytu _w Czechosłowacji delegacji Urzędu do Spraw Wyznań w czasie od 16 do 27 lipca 1963 r., k. 23-26; AAN, UdsW, 133/3, Program, k. 2

${ }^{13}$ AAN, UdsW, 133/3, Aktualne konfiguracje w Watykanie, k. 25-77

${ }^{14}$ AAN, UdsW, 133/3, Program, k. 3

${ }^{15}$ AAN, UdsW, 133/3, [Luźna notatka], k. 12

${ }^{16}$ Komitet tej organizacji składał się ze 107 członków w tym trzy osoby z Polski. AAN, UdsW, 133/3, [Luźna notatka], k. 12

${ }^{17}$ AAN, sygn. 136/7, Notatka w sprawie przygotowania konferencji urzędów do spraw wyznań krajów socjalistycznych, k.1

${ }^{18}$ Tamże. 
poszczególnymi delegacjami ${ }^{19}$. Zagadnienie dotyczące Watykanu i odbywanego w tym czasie Soboru okazało się tak obszerne, że uczestnicy narady postanowili za sugestią przedstawicieli węgierskich, zorganizować dodatkowe spotkanie tyko temu poświęcone. O jego przygotowanie i przeprowadzenie w Warszawie poproszono stronę polską, jako najbardziej ze wszystkich delegacji kompetentną i najbardziej doświadczoną, z powodu największej liczby katolików i silnej pozycji Kościoła w tym kraju. Wstępnie planowano tę konferencję na sierpień tego roku. Termin na przygotowania okazał się nierealny, za krótki. Nie był on też po myśli czynników partyjnych. W tej sytuacji Biuro Polityczne KC PZPR poleciło UdsW w Warszawie zorganizować ją dopiero w 1967 r., czyli po zakończeniu Wielkiej Nowenny i obchodów millenijnych.

$\mathrm{Na}$ konferencję warszawską zaproszono delegacje urzędów do spraw wyznań i zainteresowanych wydziałów KC partii komunistycznych i robotniczych z: ZSRR, CSRS, NRD, Węgier, Bułgarii, Rumunii ${ }^{20}$. Odbyła się w dniach 25-29 września. Wzięli w niej udział ze strony ZSRR: Władimir Aleksiejewicz Kurojedow - przewodniczący Rady ds. Religii, P.W. Makarcew - zastępca przewodniczącego Rady ds. Religii, E.G. Lisawcew - instruktor KC KPZR, P.K. Kuroczkin - zastępca dyrektora Instytutu Nauk Ateistycznych przy Akademii Nauk Społecznych KC KPZR. Delegację Czechosłowacką reprezentowali: Karol Hruza - dyrektor Sekretariatu ds. Wyznań przy Ministerstwie Kultury i Informacji, Andrej Belańsky - pełnomocnik ds. Wyznań przy Słowackiej Radzie Narodowej, Lubomir Valchaš - kierownik Samodzielnego Sektora Wyznań w Wydziale Ideologicznym. KC KPCz, Jan Diviš - inspektor Sekretariatu ds. Wyznań. Stronę węgierską reprezentowali: Józef Prantner - przewodniczący Urzędu ds. Wyznań, Imre Mikłos - wiceprzewodniczący UdsW, Istvan Balio - zastępca kierownika Wydziału Propagandy KC WSPR, Istvanne Gyulai - sekretarz delegacji. Niemcy (NRD) reprezentowali: Hans Seigewasser - Sekretarz Stanu, Willi Barth - kierownik Wydziału KC SED, Hans Weise - dyrektor Departamentu, Rudi Bellmann - instruktor KC SED. Przedstawicielami Bułgarii byli: Michał Kjuczułow - przewodniczący Komitetu do Spraw Religii Prawosławnej i Kultów Religijnych przy Ministerstwie Spraw Zagranicznych, Weliko Sawow - instruktor KC BPK. Stronę polską reprezentowali: A. Skarżyński - dyrektor Urzędu do Spraw Wyznań, Jan Bohdan - wicedyrektor Urzędu do Spraw Wyznań, Stanisław Pypno - inspektor KC PZPR i Serafin Kiryłowicz ${ }^{21}$. Uczestnicy spotkania liczyli uda im się wspólnie

\footnotetext{
${ }^{19}$ AAN, UdsW, sygn. 136/4, Pismo Sekretarza do Spraw Kościelnych Stanu Hans Seigewassera do T. Żabińskiego Dyrektora Urzędu do Spraw Wyznań, b.d. k. 1.

${ }^{20}$ Razem około 18 osób z zagranicy oraz ze strony polskiej udział dwie osoby z Wydziału Administracyjnego KC PZPR, trzy osoby z Urzędu do Spraw Wyznań. AAN, sygn. 136/9, Notatka w sprawie przygotowania konferencji urzędów do spraw wyznań krajów socjalistycznych, k. 3 .

${ }^{21}$ AAN, UdsW, sygn.136/9, Protokół z konferencji przedstawicieli urzędów wyznaniowych krajów socjalistycznych Warszawa 25-29 wrzesień 1967 r., k. 1-2; AAN,136/10, Pismo Kierownika sekretariatu do spraw kościelnych Ministerstwa Kultury i Informacji Kareła Hruza do A. Skarżyńskiego Dyrektora Urzędu do Spraw Wyznań w Warszawie, Praga 12.października 1967, k. 50; NAP, SPLC, Program, k. 1-3.
} 
„wypracować odpowiednie formy” pracy dla urzędów wyznaniowych i skonsolidować wysiłki w działaniach wobec Kościoła katolickiego.

Pierwotnie konferencja warszawska miała się skoncentrować na dwóch zagadnieniach: omówieniu sytuacji w Kościele katolickim w przededniu III sesji Soboru Watykańskiego i podsumowaniu wyników II Ogólnochrześcijańskiego Zgromadzenia Pokojowego ${ }^{22}$. Jednak z powodu przesunięcia terminu zgromadzenia, zmodyfikowano program. W ramach referatu wprowadzającego podjęto temat Nowa polityka Watykanu ${ }^{23}$, który został przygotowany przez Urząd do Spraw Wyznań PRL. Przedstawiono w nim politykę wewnątrzkościelną i zewnętrzną Watykanu w ostatnich latach, ze szczególnym uwzględnieniem polityki Watykanu wobec krajów socjalistycznych oraz na ich tle działalność Episkopatu polskiego ${ }^{24}$. Warto w tym miejscu zaznaczyć, że do konferencji w Mariańskich Łaźniach w $1961 \mathrm{r}$. zagadnienia dotyczące polityki watykańskiej przygotowywali zawsze przedstawiciele ZSRR, na wszystkich późniejszych spotkaniach problem ten przedstawiali urzędnicy z Polski. W kolejnej części zjazdu podjęto temat dotyczący przebiegu II Ogólnochrześcijańskiego Zgromadzenia Pokojowego w Pradze oraz wnioski co do dalszej działalności Chrześcijańskiej Konferencji Pokojowej25. Tę kwestię przygotował na prośbę strony polskiej Departament Spraw Kościelnych Ministerstwa Szkolnictwa i Kultury CSRS ${ }^{26}$.

Pierwszy referat wywołał duże zainteresowanie. Był podzielony na trzy części: Watykan w krajach socjalistycznych, kapitalistycznych i trzecim świecie. Wywiązała się ożywiona dyskusja. W wielu wystąpieniach przewijał się lęk przed rzekomym niebezpieczeństwem grożącym państwom socjalistycznym ze strony Watykanu. Z zawartymi tezami referatu zgodziły się wszystkie delegacje. Zastanawiano się jak aktywnie wpływać na politykę Watykanu. Przedstawiciele delegacji czechosłowackiej odnosząc się do przedstawionych tez referatu stwierdzili, że przedstawiona analiza jest bliska ich poglądom o polityce watykańskiej. Wyróżnili następujące kierunki polityki Watykanu: „Dążenie do rozszerzenia swych wpływów i umocnienia siły Kościoła w świecie. Temu celowi służy modernizacja metod działania i dostosowania się do nowych warunków, modernizacja ideologii i polityki, kultu i teologii”. Zwrócili również uwagę na rolę jaką Kościół zajmuje w ruchu ekumenicznym i jego stopniowe działania w celu zjednoczenia Kościołów chrześcijańskich po swoją egidą. W ich opinii ,główną treścią polityki Kościoła jest neokapitalizm. Z drugiej jednak strony polityka watykańska zawiera również pewne nowe, realne momenty", które powinno się wykorzystać w in-

${ }^{22}$ AAN, sygn. 136/7, Notatka w sprawie przygotowania konferencji urzędów do spraw wyznań krajów socjalistycznych, k. 1

${ }^{23}$ NAP, SPLC, Nowa polityka Watykanu, k. 1-7.

${ }^{24}$ Treść referatu wszystkim uczestnikom spotkania przedstawił J. Bohdan. AAN, sygn. 136/9, Notatka w sprawie przygotowania konferencji urzędów do spraw wyznań krajów socjalistycznych, k. 3 .

${ }^{25}$ Adwentyści a ekumenizm, http://smoktadeusz.republika.pl/teologia.html (dostęp: 02.02.2017).

${ }^{26}$ AAN, sygn. 136/9, Notatka w sprawie przygotowania konferencji urzędów do spraw wyznań krajów socjalistycznych, k. 3. 
teresie socjalizmu „dla wzajemnego zrozumienia międzynarodowego"27. Zwrócili uwagę, że współczesny katolicyzm nie jest jednolity, ale antykomunistyczny. Zasugerowali zebranym sposób postępowania wobec tej międzynarodowej instytucji - „Jeśli mamy podważać antykomunistyczny charakter polityki watykańskiej, winniśmy popierać te postępowe elementy w Kościele. Zróżnicowanie w Kościele należy wykorzystać przeciwko proamerykańskiej polityce Watykanu" ${ }^{28}$. Nadto delegat czechosłowacki (Hruza) wysunął propozycję podjęcia wspólnych działań, mających na celu „wykorzystanie ośrodków katolickich do walki z Watykanem". Wniosek czechosłowacki wykorzystania organizacji katolickich $\mathrm{w}$ walce $\mathrm{z}$ Watykanem poparł S. Kiuczukow z Bułgarii i zaproponował wypracowanie odpowiednich metod pracy w celu lepszego wykorzystania katolickich organizacji, gdyż ,sytuacja w ruchu katolickim wymaga wypracowania pewnych teoretycznych założeń" ${ }^{29}$. Węgrzy natomiast wskazali, że „Watykanowi chodzi o wyszukanie nowych form w walce przeciwko komunizmowi”. Dlatego ich zdaniem - państwa socjalistyczne nie powinny dopuścić do tego, by „Watykan zrealizował swoje cele" 30 . Madziarzy domagali się również, częstszych spotkań poświęconych problematyce watykańskiej. W przeciwieństwie do innych delegacji stanęli na stanowisku,

że nie należy odrzucać wszelkich zbliżeń z Watykanem, ponieważ życie zmusza Watykan do podejmowania kroków wbrew jego woli, np. rokowania. Nie możemy odrzucać takich inicjatyw. Jeżeli jednak te inicjatywy skierowane są przeciw nam, to je odrzucamy. Jeśli rokowania wyrażają realizm, to rokujemy. Zdajemy sobie sprawę, że takie rokowania, zbliżenia są do pewnego stopnia ryzykowne, jednak rozwój sytuacji przemawia za tym, żeby brać w nich udział.

Przedstawiciel węgierski Istvan Balio zwrócił także uwagę na „możliwość podejmowania w skali międzynarodowej wspólnych akcji” i nie odrzucania takich okazji. Wykazując większy realizm sprzeciwił się propozycji czechosłowackiej „wykorzystania ośrodków katolickich do walki z Watykanem”, uważając, że takie działania byłyby bardziej szkodliwe dla państw socjalistycznych". W celu powstrzymania działalności dyplomatycznej Watykanu, zaproponował „skoordynowanie działań poprzez wspólne konsultacje, wymianę informacji, nawet $w$ takich sprawach, które będę interesowały tylko nasz kraj" ${ }^{31}$. Zdaniem delegatów z NRD „Watykan usiłuje prowadzić wyrafinowaną politykę ,zmiękczania” krajów socjalistycznych ${ }^{32}$. Dyskusja ta, jak przyznali jej uczestnicy, uświadomiła potrzebę częstszych konsultacji w kwestii Watykanu i polityki wobec Kościoła katolickiego w krajach bloku wschodniego. Na kolejnych spotkaniach ten temat nieustannie się przewijat.

${ }^{27}$ AAN, UdsW, sygn.136/9, Protokół z konferencji przedstawicieli urzędów wyznaniowych krajów socjalistycznych Warszawa 25-29 wrzesień 1967 r., k. 3

${ }^{28}$ Tamże, k. 4

${ }^{29}$ Tamże, k.8-9

${ }^{30}$ Tamże, k. 5

${ }^{31}$ AAN, UdsW, sygn.136/9, Protokół z konferencji przedstawicieli urzędów wyznaniowych krajów socjalistycznych Warszawa 25-29 wrzesień 1967 r., k. 7

${ }^{32}$ Tamże. 
Drugim ważnym zagadnieniem poruszonym na spotkaniu w Warszawie była sprawa II Chrześcijańskiej Konferencji Pokojowej w Pradze, organizacji cieszącej się poparciem krajów socjalistycznych, gdyż była kolejnym obszarem oddziaływania na ludzi wierzących, w duchu ideologii komunistycznej. Wstępem do dyskusji o ChKP był referat delegata Czechosłowacji - Hruzy. W swoim wystąpieniu skupił się na trzech wątkach: działalność ChKP, perspektywy organizacji oraz główne idee, koncepcje konferencji. Zapoznał wszystkich z wynikami II Konferencji, która jego zdaniem pozytywnie zrealizowała wyznaczone jej zadania wśród chrześcijan, czego wyrazem było uczestnictwo w niej ponad 1.000 duchownych $\mathrm{z}$ całego świata ${ }^{33}$. Pochwalił się, że organizacja ta $\mathrm{w}$ wielu krajach (m.in. Holandii, Urugwaju, Argentynie, Japonii, RFN) założyła swoje lokalne komitety, które wspierały finansowo jej różne akcje, np. komitet w RFN ofiarował na pomoc Narodowego Frontu Wyzwolenia Wietnamu 60.000 marek. Prelegent podkreślił, że ChKP stwarza dobre warunki do forsowania w krajach Zachodniej Europy uchwał ze spotkania partii robotniczych i komunistycznych w Karłowych Warach oraz neutralizowania w nich przejawów działalności antykomunistycznej. Analizując działalność ruchu wskazano na słabe strony jego działalności, np. brak ,zaktywizowania” szerokich mas niewierzących, czy koncentrowanie się na wydawaniu rezolucji, odezw zamiast konkretnej działalności wśród wierzących. Dostrzeżono też problem braku szerszej współpracy z tym ruchem, szerokich środowisk katolickich z krajów socjalistycznych. Jako przyczynę tego stanu rzeczy podano „żelazną dyscyplinę w Kościele rzymskokatolickim”. Na tym spotkaniu zastanawiano się, czy ten ruch ma orientować się na Watykan, czy na lewicowy ruch postępowych katolików. Zwrócono także uwagę na trudności w pozyskaniu współpracowników z kręgu duchownych protestanckich w Afryce, które wynikały decyzji Światowej Rady Kościołów i Swiatowego Związku Laterańskiego. Te instytucje zagroziły duchownym afrykańskim wstrzymaniem pomocy w przypadku, gdy będę współpracować z ChKP ${ }^{34}$. Jako atut ChKP uznano brak obciążenia kolonializmem, co znajdowało uznanie i przysparzało zwolenników w krajach Afryki i Azji. Potwierdzeniem tej tezy był wzrost liczby studentów z tych kontynentów na uniwersytecie w Pradze. Zwrócono również uwagę na to, że chociaż protesty tego ruchu wobec wojny w Wietnamie, przysparza zwolenników w krajach zachodnich, to jednak jest on krytykowany za ,zbyt mocne, polityczne zaangażowanie się po stronie Związku Radzieckiego". Innym sukcesem tego ruchu - jak podkreślano na naradzie - było uznanie go przez Światową Radę Kościołów, Światowy Związek Luterański, Światowy Związek Prezbiterianów i Centralę Kościołów Metodystów oraz ulokowanie wielu działaczy ChKP na różnych stanowiskach w tych organizacjach. Dzięki czemu udało się państwom socjalistycznym osłabić działalność antykomunistyczną w światowych organizacjach Kościołów oraz wywierać wpływ na nie, dzięki czemu udaje się rozpowszechniać poprzez nie opinii o nieskrępowanej działalności Kościołów w krajach socjalistycznych. W wyniku dyskusji postanowiono, mimo pewnych uchybień i niejasności

\footnotetext{
${ }^{33}$ Tamże, k. 11

${ }^{34} \mathrm{Był}$ to ruch duchownych protestanckich. Tamże, k. 12
} 
w działalności ChKP, wspierać i wykorzystać go do przekonywania wierzących, że „chrześcijaństwo nie może służyć siłom imperialistycznym, jako narzędzie antykomunizmu"35. Polecono także, aby ChKP rozwijała bliższą współpracę chrześcijan z organizacjami niechrześcijańskimi i ruchami postępowymi i w ten sposób wzmacniała w nich swe wpływy. Zaproponowano również wypracowanie jednolitej koncepcji działalności ChKP przy współpracy przywódców Kościołów. Niektórzy postulowali nawet, aby ChKP potępiła Watykan za nieuznawanie granic na Odrze i Nysie ${ }^{36}$. Wszyscy uczestnicy spotkania pozytywnie ocenili działalność ruchu i proponowane zamiany $\mathrm{w}$ jego działalności, wynikających z zachodzących zmian w relacjach międzynarodowych. Sugerowano większe zaktywizowanie działaczy „postępowych” w świecie protestanckim, w Światowej Radzie Kościołów i innych światowych organizacjach niekatolickich. Planowano w ten sposób zdobyć zwolenników i zrealizować politykę pokoju w duchu socjalistycznym ${ }^{37}$. Zebranie wykorzystano również do wypracowania wspólnej polityki personalnej w tym ruchu, jego struktur organizacyjnych oraz kierunków działania na arenie międzynarodowej ${ }^{38}$. Przedstawiciele $\mathrm{z}$ Węgier $\mathrm{w}$ kwestiach personalnych zgodzili się na dokooptowanie do ChKP, bpa Barta oraz powołanie wspólnego komitetu spośród uczestników tego spotkania, który wypracowałby wspólne zadania dla $\mathrm{ChKP}^{39}$. Zwrócono uwagę na potrzebę zaktywizowania Chrześcijańskiej Konferencji Pokojowej w krajach trzeciego świata oraz konieczność opracowania koncepcji nawiązania kontaktów z katolikami ${ }^{40}$. Towarzyszom czeskim zależało głównie na tym, aby wszystkie delegacje na tym spotkaniu przyjęły jako zasadnicze i wiążące następujące konkluzje:

Chrześcijańska Konferencja Pokojowa jest organizacją międzynarodową, która potrafiła zdobyć wpływ na arenie międzynarodowej i która zdolna jest nadal przy pomocy swoich specyficznych środków być jednym z instrumentów działania socjalistycznej polityki zagranicznej; Chrześcijańska Konferencja jest ważnym instrumentem walki o światowy pokój a także jako przeciwwaga antykomunizmu; Głównym celem Chrześcijańskiej Konferencji jest działalność obliczana na zagranicę. Konferencja nie może być traktowana jako enklawa Wschodu, ale jako organizacja grupująca różnorodne siły postępowe Wschodu i Zachodu; Podstawowe zasady Chrześcijańskiej Konferencji przyjęte na ostatniej Konferencji są prawidłowe. Nasz nacisk na działalność konferencji w płaszczyźnie działalności międzynarodowej, w kierunku jednoczenia frontu postępowego wynika z zadania jednoczenia Kościołów na specjalnej platformie. Nie ma jednak uzasadnienia polityczne kierowanie tymi Kościołami. Nie może to być zadaniem konferencji. Chrześcijańska Konferencja musi stymu-

${ }^{35}$ AAN, UdsW, sygn.136/9, Protokół z konferencji przedstawicieli urzędów wyznaniowych krajów socjalistycznych Warszawa 25-29 wrzesień 1967 r., k. 13

${ }^{36}$ Tamże, k. 14

${ }^{37}$ Tamże, k. 16

${ }^{38}$ Tamże, k. 15,18

${ }^{39}$ Węgrzy zaproponowali, jako dowód ścisłej współpracy wszystkich państw socjalistycznych, oprócz siedziby Centrum ruchu w Pradze, rezydowanie jego przewodniczącego w Budapeszcie. Tamże, k. 17

${ }^{40}$ Tamże, k. 23 
lować, jednoczyć, uzgadniać różnorodne prądy nurtujące chrześcijaństwo. To zadanie może być realne tylko wtedy, gdy konferencja stanie po stronie postępu, przejawi pryncypalność, odrzuci elementy sekciarstwa; Poszukiwanie nowych form politycznego oddziaływania jest zadaniem głównym przyszłych konferencji; Działalność Konferencji w odniesieniu do problemów walki o pokój i walki z antykomunizmem musi być podporządkowana zasadom polityki zagranicznej krajach Socjalistycznych; Chrześcijańska Konferencja nie może być automatycznie transmisją wszystkich interesów poszczególnych państw socjalistycznych, musi ona być jednak taka, aby dla socjalistycznej polityki zyskiwać zwolenników; Wpływ obozu socjalistycznego na działalność konferencji należy realizować przede wszystkim przez teologów krajów socjalistycznych; Należy dbać o to, aby w konferencji nie uczestniczyły osoby o poglądach antykomunistycznych; W obecnej sytuacji kiedy imperializm rozwija antysocjalistyczny kampanię, w której instrumentem jest ruch duchowieństwa, zgodnie z rezolucję przyjęty na ostatniej konferencji należy mobilizować wszystkie siły chrześcijańskie, siły tych, którzy w swoich poglądach religijnych znajdują motywy na rzecz działania dla pokoju ${ }^{41}$.

Mimo ich zabiegów, przedstawiciele Węgier i NRD przeforsowali jednak podjęcie dalszych prac nad zasadami tego ruchu i powołanie w tym celu grupy roboczej $^{42}$.

Kolejnym tematem wspólnej narady było wypracowanie wspólnej strategii wobec Światowej Rady Kościołów (ŚRK), po wejściu w jej skład Rosyjskiej Cerkwi Prawosławnej i innych Kościołów chrześcijańskich z krajów bloku wschodniego. Referat na ten temat wygłosił Kurojedow. Zebrani stwierdzili, że nie należy nie doceniać jego działalności, ale podchodzić ostrożnie i pozytywnie wpływać przez odpowiednie przygotowanie przedstawicieli Kościołów z krajów socjalistycznych do pracy w tej organizacji oraz uniemożliwić jej antykomunistyczną działalnośćc ${ }^{3}$. W dyskusji zwrócono uwagę na zmianę postawy Watykanu wobec tej organizacji. Zdaniem niektórych uczestników, celem Watykanu jest rozczłonkowanie Kościołów: prawosławnego, luterańskiego, ewangelickiego, zrzeszonych w ŚRK ${ }^{44}$. Podkreślono, że przedstawiciele krajów socjalistycznych mają dużo większe możliwości wpływania na kierunek działalności tej instytucji niż na politykę Watykanu. W związku z tym postulowano lepszą konsolidację stanowisk i ,jednolitość działania obozu socjalistycznego", aby mógł on mieć w ŚRK liczne delegacje i realizował poprzez jego struktury swoje propozycje ${ }^{45}$. Doszli również do wniosku, że ŚRK jest doskonałym narzędziem do zwiększenia szans na przeciwstawienie się „,siłom reakcyjnym i rozszerzenia naszego punktu widzenia" ${ }^{46}$.

Uczestnicy poparli wniosek dotyczący utrzymania pozycji jaką przedstawiciele krajów socjalistycznych zdobyli w kierownictwie tej instytucji oraz życze-

${ }^{41}$ AAN, UdsW, sygn.136/9, Protokół z konferencji przedstawicieli urzędów wyznaniowych krajów socjalistycznych Warszawa 25-29 wrzesień 1967 r., k. 23-24.

${ }^{42}$ Tamże, k. 25.

${ }^{43}$ Tamże, k. 26.

${ }^{44}$ Tamże, k. 27.

${ }^{45}$ Tamże, k. 28, 33.

${ }^{46}$ Tamże, k. 32. 
nie delegacji radzieckiej, aby reprezentantem krajów socjalistycznych w ŚRK był przedstawiciel Rosyjskiej Cerkwi Prawosławnej. Komuniści postanowili brać udział w ŚRK, aby neutralizować jej działalność i wykorzystywać jej trybunę dla rozpowszechniania idei marksistowsko-leninowskich ${ }^{47}$. Na zakończenie wspólnej narady, na prośbę delegacji węgierskiej podjęto kwestię „Dialogu między komunistami, a chrześcijanami” ${ }^{\prime 4}$. Zebrani stwierdzili, że nie są przeciwko wszelkim formom dialogu, ale

nie do przyjęcia jest dla nas taki dialog z Kościołem, którego tendencją jest popieranie wrogich sił kapitalizmu przeciwko krajom socjalistycznym. Istota dialogu pomiędzy marksistami, a chrześcijanami nie może być dyskusją samą dla siebie, ale mogą być dyskusje na temat, jak wspólnie stwarzać warunki dla dobra ludzkości. Musi więc dojść do produktywnej współpracy ${ }^{49}$.

Na zakończenie narady warszawskiej postanowiono ,śledzić wszystkie kroki Kościoła katolickiego i innych organizacji katolickich, głęboko analizować jego działalność, pokazywać jego klasowy charakter" oraz organizować regularne konsultacje i uzgadniać wspólną politykę wobec niego. Zgłoszono także wniosek o podjęcie działan mających na celu narzucanie Watykanowi pomysłów socjalistycznych oraz o analizowanie jego polityki, aby „móc oszukać starego chytrego przeciwnika" 50 .

Zagadnieniom ChKP poświęcono także kolejną naradę. Odbyła się ona w Pradze w dniach 17-19 lutego $1970 \mathrm{r}$. Uczestniczyli w niej urzędnicy wyznaniowi z Bułgarii, Czechosłowacji, Polski, Węgier, NRD i ZSRR. (D. Todorow, K.Hruza, Hrasek, Homala i Kmet, H. Weise, Miklos, Giulai, Dusik, Kiryłowicz, Makarcew $)^{51}$. Odbywała się ona w stolicy Czechosłowacji w szczególnej atmosferze - po pacyfikacji przez wojska Układu Warszawskiego tzw. „Praskiej wiosny”. W związku z zawirowaniami ChKP w 1968 r., poddano pod dyskusję uczestników kwestię dalszego jej istnienia. Gospodarze spotkania nie ukrywali, że mieli problem z tą organizacją, choć $\mathrm{w}$ przeszłości odnosili duże sukcesy dzięki jej działalności. Jak podkreślali „znaczna część teologów, zarówno w Europie, jak i w trzecim świecie, pomagała nam w realizacji pokojowej polityki Światowej Rady Pokoju". Organizacja wymknęła się im jednak spod kontroli, dlatego poprosili innych o pomoc w rozwiązaniu problemu. Charakteryzując sytuację ChKP podali, że utworzyły się w niej dwa obozy: obóz działaczy postępowych i obóz działaczy reakcyjnych, a co gorsze ,zainicjowana została przez kraje socjalistyczne. Za pieniądze tych krajów ChKP działała, ale tańczyła nie tak, jak my byśmy

${ }^{47}$ Tamże, k. 35.

${ }^{48}$ Był też poruszony temat „Znaczenia Towarzystwa Pawłowego”. Tamże, k. 35.

${ }^{49}$ Tamże, k. 39.

${ }^{50} \mathrm{~W}$ kwestii Watykanu postulowano, aby podjąć dogłębne badanie działalności partii komunistycznych w świecie, które w różnym okresie prowadziły dialog ze Stolicą Apostolską. W ten sposób, jak sądzono, znajdą się odpowiedzi na wiele pytań nurtujących komunistów co do polityki wobec Watykanu. AAN, UdsW, sygn.136/9, Protokół z konferencji przedstawicieli urzędów wyznaniowych krajów socjalistycznych Warszawa 25-29 wrzesień 1967 r., k. 44.

${ }^{51}$ AAN, UdsW, sygn.144/15, Notatka. Narada przedstawicieli Urzędów do Spraw Wyznań BEL. CSRS, NRD, PRL WRL, ZSRR w Pradze dn. 17 - 19 lutego 1970 r. poświęcona ChKP, k. 1-2.. 
chcieli. Pozwolono siłom zachodnim, aby przemycały swoją ideologię do naszych krajów". Komuniści z Czechosłowacji nie ukrywali, że organizacja powstała po to, aby przenosić na Zachód komunistyczną ideologię pokoju. W dyskusji zasugerowano dwie propozycje rozwiązania tego problemu, a mianowicie - spowodowanie rozłamu w ChKP i zbudowania nowego ruchu, albo podjęcie próby ugody z przeciwnikami. Zebrani nawiązując do wyników ostatniego Zgromadzenia Ogólnego ChKP, stwierdzali, że delegacje z krajów socjalistycznych pracowały dobrze według instrukcji swoich Urzędów do Spraw Wyznań ${ }^{52}$. Wybrano drugie rozwiązanie. Następnie zastanawiano się jak jeszcze bardziej zaktywizować Kościoły chrześcijańskie w walce o pokój w koncepcji państw bloku wschodniego, gdyż jak zauważyli urzędnicy z Czechosłowacji:

Tam gdzie nas nie ma, gdzie my nie pracujemy, tam zamiast nas pracuje wróg. Kościoły zostały wciągnięte do walki przeciwko socjalizmowi w różnej formie. Imperializm będzie wykorzystywał Kościoły do tej walki. Pracują nad tym i Watykan i ŚBK i światowy Kahał Żydów. W tej ogólnej sytuacji koniecznym wydaje się wciągnięcie do walki o pokój po naszej stronie teologów i aktywistów kościelnych, Światowa Rada Pokoju wzywa do tego postępowych działaczy kościelnych.

W związku z tym podjęto sprawę udziału delegacji Kościołów luterańskich z krajów Socjalistycznych w Zgromadzeniu Światowej Federacji Luterańskiej w Porto-Alegre ${ }^{53}$.

Ważne dla urzędników wyznaniowych z krajów socjalistycznych było spotkanie w Sofii, w Bułgarii. Było ono kontynuacją narady moskiewskiej z lipca 1969 r. ${ }^{54}$ Odbyło się ono w dniach 22-26 października 1972 r. Wzięli w nim udział kierownicy Urzędów ds. Wyznań: Bułgarskiej Republiki Ludowej, Czechosłowackiej Republiki Socjalistycznej, Mongolskiej Republiki Ludowej, Niemieckiej Republiki Demokratycznej, Polskiej Rzeczypospolitej Ludowej, Socjalistycznej Republiki Rumunii, Węgierskiej Republiki Ludowej i Związku Socjalistycznych Republik Radzieckich ${ }^{55}$. Przedstawiciele Rumunii, którzy od wielu lat uchylali się od udziału w tych konferencjach oraz delegacje Kuby i Mongolskiej Republiki Ludowej, którzy dotychczas w nich nie uczestniczyli, przybyli na wniosek Rady ds. Wyznań ZSRR.

Wiodącym tematem spotkania była kwestia dotycząca Watykanu i jego działań wobec państw bloku wschodniego. Tak jak na wcześniejszych spotkaniach, w dyskusję wprowadził wygłoszony przez A. Skarżyńskiego referat, o nowej polityce wschodniej Watykanu. Szef polskiego UdsW przedstawił trzy zasadnicze problemy: stosunek Watykanu do ideologii komunistycznej; stosunek Watykanu do bloku państw komunistycznych; stosunek Watykanu do poszczególnych

${ }^{52}$ Tamże, k. 3-4.

${ }^{53}$ Tamże, k. 1-2.

${ }^{54}$ Tamże, k. 22; Tamże, sygn.136/13, Pismo A. Skarżyńskiego do Towarzysza Stanisław Kania Zastępcy członka Biura politycznego 1 Sekretarz KC PZPR, wrzesień 1972, k. 15-15.

${ }^{55}$ AAN, UdsW, sygn. 136/13, Notatka dot. spotkania kierowników Urzędów d/s Wyznań krajów socjalistycznych odbytego w dniach od 22 do 26 października 1972 r. w Sofii, k. 134; tamże, Wykaz delegacji biorących udział w spotkaniu w Sofii, k. 190-192. 
państw komunistycznych. Jego uzupełnieniem był koreferat wygłoszony przez przewodniczącego delegacji radzieckiej W.A. Kurojedowa pt. O niektórych problemach naszych stosunków z Watykanem ${ }^{56}$. Referat A. Skarżyńskiego spotkał się z dużym uznaniem słuchaczy. Delegacje z Węgier, Czechosłowacji, NRD, Rumunii, Mongolii, ZSRR poparli wszystkie propozycje zasugerowane przez polską stronę odnośnie wspólnych działań wobec Watykanu. Kurojedow przedstawiając relacje ZSRR z Watykanem poinformował uczestników spotkania, że „W ostatnich czasach Watykan pod różnymi pozorami stara się wysyłać do ZSRR najbardziej wpływowych hierarchów kościelnych", aby w ten sposób każda taka wizyta zwracała uwagę światowej opinii publicznej i wywierała wpływ na ożywienie Kościoła katolickiego w ZSRR oraz dawała możliwość przedstawicielom Watykanu przedkładania różnych problemów i pretensji dotyczących położenia tego Kościoła w ZSRR. W podjętej dyskusji podkreślano, że Watykan dąży do nawiązania kontaktów z państwami socjalistycznymi na różnych płaszczyznach celem zawarcia porozumienia i wznowienia stosunków dyplomatycznych. Polscy komuniści zaproponowali, aby nie nadawać kontaktom z Watykanem charakteru oficjalnych stosunków dyplomatycznych. Delegaci z ZSRR w ogóle byli im przeciwni, ponieważ jak się wyrazili „,nawiązanie stosunków dyplomatycznych z Watykanem może się okazać korzystnym tylko dla Watykanu". W debacie tej zwrócono szczególnie uwagę na rzekomy antykomunizm Watykanu i jego taktykę dążącą do rozbicia obozu socjalistycznego. Dla nich Watykan „stanowi główną rezerwę imperializmu" w zwalczaniu komunizmu, rozbiciu jedności krajów socjalistycznych". W szystkie delegacje zgodziły się z opinią urzędników wyznaniowych z ZSRR, że kwestia relacji z Watykanem jest istotna dla wszystkich państwa socjalistycznych i musi być jasno określone wspólne stanowisko. Przedstawiciele Kremla zaproponowali zebranym, aby ,„po dyskusji nad polityką Watykanu przyjąć komunikat, w którym określano by nasze stanowisko wobec Watykanu"57. Wypracowania wspólnego, jednolitego stanowiska wobec Watykanu chcieli też przedstawiciele pionu wyznaniowego z Czechosłowacji. Ich zdaniem „Watykan usiłuje obecnie stworzyć nowe warunki, które pomogłyby mu na rozwiązanie jego podstawowych problemów tj. kryzysu wewnętrznego, którego nie przezwyciężył II Sobór". Poskarżyli się w czasie spotkania na pro memoria jakie otrzymali od abpa A. Casarolego, w którym oskarżał rząd CSSR o popieranie ruchu księży postępowych, dążący do dyskredytacji hierarchii kościelnej w Czechosłowacji i niezgadzanie się na przedstawione przez Watykan kandydatury na biskupów oraz uniemożliwianie swobody wyznawania wiary. W ich opinii, Watykan dąży do poróżnienia Czechosłowacji z innymi bratnimi krajami, czego dowodem są stawiane im zarzuty o niechęć prowadzenia rozmów, gdy inne kraje socjalistyczne

${ }^{56}$ AAN, UdsW, sygn. 136/13, Notatka dot. spotkania kierowników Urzędów d/s Wyznań krajów socjalistycznych odbytego w dniach od 22 do 26 października 1972 r. w Sofii, k. 134-135; tamże, Aktualna polityka Watykanu w stosunku do państw socjalistycznych, k. 148-163; tamże, Nowa polityka Watykanu wobec państw socjalistycznych po II Soborze Watykańskim, k. 180-189.

${ }^{57}$ AAN, UdsW, sygn. 136/13, Notatka dot. spotkania kierowników Urzędów d/s Wyznań krajów socjalistycznych odbytego w dniach od 22 do 26 października 1972 r. w Sofii, k. 135. 
porozumiały się z Watykanem ${ }^{58}$. Również Niemcy byli przekonani, że „Watykan stara się dzielić kraje socjalistyczne", dlatego nakłaniali do zacieśnienia współpracy i większej jedności. Węgrzy natomiast podkreślali, że nawiązali kontakty z Watykanem, aby wykorzystać je dla celów polityki pokojowej oraz uzyskać zniesienie kar kanonicznych wobec „księży postępowych”. Nie zgodzili się jednak, mimo nacisków z jego strony, na nawiązanie stosunków dyplomatycznych. Uważali bowiem, że nawiązanie stosunków dyplomatycznych z Watykanem nie jest sprawą pojedynczego kraju socjalistycznego, ale sprawą wszystkich krajów socjalistycznych". Dla nich najważniejszym problemem w rozmowach z abp. A. Cassarolim była sprawa obsady wakujących diecezji i kard. Mindszenthy'ego ${ }^{59}$ - co zajęło 4/5 czasu obrad ${ }^{60}$. Także Bułgarzy byli zdania, że „nie należy zawierać stosunków dyplomatycznych z Watykanem, ale utrzymywać z nim bieżące kontakty". Przedstawiciele z Rumunii byli zdania, że polityka każdego kraju socjalistycznego w stosunku do Watykanu określana jest przez ,specyficzną sytuację każdego kraju" ${ }^{61}$. W ich rozumieniu podejście do działań Watykanu musi być precyzyjne i ,uwzględniać różnorodność problematyki wyznaniowej w poszczególnych krajach socjalistycznych". W związku z tym muszą być uwzględniane „niuanse w taktyce”. Nie doszło mimo propozycji, do wydania wspólnego dokumentu wyrażającego jednolite stanowisko resortów wyznaniowych państw socjalistycznych w sprawie Watykanu. Uczestnicy narady nie otrzymali pełnomocnictw swoich krajów w tej sprawie. Każda jednak delegacje otrzymała tekst opracowanej przez komisję w składzie: A. Skarżyński, Miklos, Hruza, uchwałę o stosunku do polityki Watykan ${ }^{62}$. Dodatkowo na spotkaniu zajęto się kwestiami Chrześcijańskiej Konferencji Pokojowej oraz Berlińskiej Konferencji Katolików ${ }^{63}$. Po raz kolejny poruszono sprawę zwiększenia roli Kościołów działających w krajach socjalistycznych w walce o pokój. Podstawą do dyskusji nad tą problematyką były referaty wygłoszone przez wiceprzewodniczącego Rady ds. Kultów Religijnych przy Radzie Ministrów ZSRR - Piotra Makarcewa i przewodniczącego Urzędu ds. Wyznań przy rządzie Federalnej Republiki Czechosłowackiej Karela Hruzę. Autorzy przedstawili sytuację w Kościołach chrześcijańskich, na tle ogólnoświatowej walki o pokój. Dopatrywali się w światowym ruchu eku-

${ }^{58}$ AAN, UdsW, sygn. 136/13, Notatka dot. spotkania kierowników Urzędów d/s Wyznań krajów socjalistycznych odbytego w dniach od 22 do 26 października 1972 r. w Sofii, k. 136.

${ }^{59}$ Kard. Józef Mindszenty (1892-1975). Święcenia kapłańskie przyjął w 1915 r. W 1944 r. został biskupem Veszprém. W 1945 r. został prymasem Węgier. Po zdobyciu władzy przez komunistów na Węgrzech, zostaje aresztowany w 1948 r. Przez sąd został skazany na dożywotnie więzienie. W 1956 r. opuścił więzienie w czasie powstania węgierskiego. Po jego upadku schronił się w ambasadzie amerykańskiej w Budapeszcie i spędził tam 15 lat. W 1971 r. w wyniku porozumienia Stolicy Apostolskiej z komunistycznym rządem węgierskim, opuścił kraj i osiadł w Wiedniu. Zmarł 6 maja 1975 r. K. Kaczmarek, Prawda i kłamstwo. Prymas Węgier Józef Mindszenty, Poznań-Warszawa 2002.

${ }^{60}$ AAN, UdsW, sygn. 136/13, Notatka dot. spotkania kierowników Urzędów d/s Wyznań krajów socjalistycznych odbytego w dniach od 22 do 26 października 1972 r. w Sofii, k. 136.

${ }^{61}$ Tamże, k. 137.

${ }^{62}$ Tamże, k. 139-140.

${ }^{63}$ Tamże, k. 134; tamże, Wykaz delegacji biorących udział w spotkaniu w Sofii, k. 190-192. 
menicznym rzekomych prób montowania antykomunistycznego frontu i pod tym kątem dokonali przeglądu poczynań Światowej Rady Kościołów i Konferencji Kościołów Europejskich, które - ich zdaniem - były pod wpływem ideowo-politycznych ośrodków zachodnioeuropejskich i finansowych. Referenci przedstawili również aktualną sytuację w ChKP, jej problemy organizacyjno-kadrowe i finansowe. Stwierdzili, że po ostrym kryzysie programowym i personalnym w latach 1969-1970, organizacja ta weszła w stadium stabilizacji i zapoznali zebranych z wykazem zadań ChKP na najbliższy okres. Po referatach rozwinęła się dyskusja. Wicedyrektor Urzędu ds. Wyznań PRL T. Duslk scharakteryzował międzynarodową działalność na rzecz pokoju, prowadzoną przez Kościoły działające na terenie Polski. Wicedyrektor Urzędu ds. Wyznań WRL - Balio stwierdził, że w stanowisku Światowej Rady Kościołów, w istocie rzeczy, niewiele się zmieniło. Nadal charakterystyczny jest dla niej antysocjalistyczny kierunek działania. W tej sytuacji, proponował nadal dążyć do zwiększenia aktywnego udziału przedstawicieli Kościołów z krajów socjalistycznych na forum ŚRK i wypracować wspólne stanowisko krajów socjalistycznych wobec wzmagającego się obecnie dążenia ŚRK i Kościołów zachodnioeuropejskich do zacieśniania współpracy z Kościołami w krajach socjalistycznych. Balio wskazał na potrzebę bardziej aktywnej postawy Kościołów z krajów socjalistycznych wobec Kościołów w krajach Trzeciego Świata, a zwłaszcza w krajach Afryki i Ameryki Łacińskiej. Zasugerował potrzebę zacieśnienia współpracy między Kościołami działającymi w krajach socjalistycznych. Takie współdziałanie mogłoby - jego zdaniem - przyczynić się do podniesienia autorytetu Chrześcijańskiej Konferencji Pokojowej. Uczestniczący w tym spotkaniu przewodniczący Rady ds. Religii przy Radzie Ministrów Mongolskiej Republiki Ludowej przedstawił zebranym sprawę wykorzystywania przez komunistów w Azji ruchu buddyjskiego, w walce o pokój we współczesnym świecie. Efektem tego spotkania było przyjęcie i włączenie przez wszystkie urzędy wyznaniowe państw socjalistycznych do strategii własnej polityki wyznaniowej wobec lokalnych środowisk chrześcijańskich oraz organizacji międzynarodowych i międzywyznaniowych, wniosków zawartych w referatach Makarcewa i Hruzy ${ }^{64}$.

Trzy lata później, w dniach 20 do 25 października 1975 r., odbyła się w Budapeszcie kolejna narada kierowników urzędów do spraw wyznań oraz przedstawicieli komitetów centralnych partii komunistycznych państw socjalistycznych. Uczestniczyli w niej przedstawiciele Bułgarii, Czechosłowacji, Mongolii, NRD, Polski, Węgier, ZSRR, po kilkuletniej przerwie z Rumunii oraz po raz pierwszy z Kuby ${ }^{65}$. Obrady dotyczyły problemów zdynamizowania działalności Kościołów z krajów socjalistycznych w walce o pokój, w warunkach odprężenia międzynarodowego". Referat wprowadzający przedstawiła strona węgierska, która skonsultowała jego treść wcześniej z poszczególnymi Urzędami. W trakcie tego spotkania ustalono główne kierunki działań państw socjalistycznych wobec międzynarodowych organizacji religijnych. Wytypowano także przedstawicieli kościołów,

${ }^{64}$ AAN, UdsW, sygn. 136/13, Informacja dot. spotkania kierowników Urzędów d/s Wyznań krajów socjalistycznych odbytego w dniach od 22-26.X. 72 r. w Sofii, k. 146-147.

${ }^{65}$ AAN, UdsW, sygn.. 136/13, Zapis protokolarny, k. 7-9. 
związków wyznaniowych i organizacji wyznaniowych z tych krajów, do władz Berlińskiej Konferencji Katolików Europy i Chrześcijańskiej Konferencji Pokojowej oraz do doraźnych akcji. Zwrócono uwagę na międzynarodowe organizacje wyznaniowe podejmujące problematykę walki o pokój w warunkach odprężenia międzynarodowego, np. Azjatycką Konferencję Buddystów na Rzecz Pokoju. $\mathrm{W}$ tej sprawie poproszono przedstawicieli z Mongolii, z kraju o starej kulturze buddyjskiej, aby podjęli się ożywiania pokojowego ruchu buddyjskiego w Azji w duchu socjalistycznym ${ }^{66}$. W kwestii Berlińskiej Konferencji Katolików Europy, rozważano propozycję strony niemieckiej utworzenia jej oddziału w Ameryce Łacińskiej. Zaproponowano dalsze jej instytucjonalne umocnienie w Europie przez powołanie czterech stałych problemowych komisji w różnych krajach. W Berlinie komisję zajmującą się zasadniczymi problemami politycznym, w Warszawa komisję od problemów rozbrojenia, w Paryżu komisję od problemów młodzieży w krajach kapitalistycznych i w Bernie, w Szwajcarii komisję nad rolą kobiety w społeczeństwie i Kościele ${ }^{67}$. Zaplanowano poszerzenie współpracy tej organizacji z przedstawicielami episkopatów krajowych, oraz instytucji watykańskich np. Papieską Komisją „Iustitia et Pax: czy organizacją „Pax Christ”. W kwestii ChKP postulowano rozciągnąć jej działalność na Amerykę Łacińską i Afrykę, zaś jej tematykę rozszerzyć na walkę z rasizmem i neokolonializmem oraz wzmocnić bazę strukturalno-organizacyjną i kadrową ChKP w Europie. Zasugerowano delegacji czechosłowackiej dalsze rozwijanie kontaktów tego ruchu ze wszystkimi postępowymi chrześcijańskimi organizacjami świata, w tym także z katolickimi np. z „Pacem in terris”, „Opus Pacis”, „Pax Christi” oraz z watykańską „Iustitia et Pax". Zebrani zgodzili się z propozycją przedstawicieli Czechosłowacji podniesienia statusu ChKP jako organizacji doradczej ONZ z grupy III (najniższej) do II. Podjęto też decyzję zwołania w 1977 r. w Pradze V Ogólnochrześcijańskiego Zgromadzenia Pokojowego. Pozytywnie oceniono przebieg Konferencji Muzułmańskiej w Samarkandzie w 1974 r., w której wzięło udział 25 państw68. W tych wszystkich proponowanych projektach chodziło komunistom - czego nie ukrywali - o „wzmożenie poprzez kanały religijne propagandy pokojowej polityki krajów socjalistycznych, demaskowanie polityki kół imperialistycznych wrogiej wobec sprawy pokoju i socjalizmu", a także o bardzie efektywne wykorzystanie przez działaczy wyznaniowych krajów socjalistycznych Światowej Rady Kościołów, Światowego Aliansu Baptystów, Światowej Federacji Laterańskiej i innych, do lansowanie idei socjalistycznego pokoju. Jednoczenie zwracali uwagę, ,aby działalność ta nie umacniała struktur kościelno-wyznaniowych i aby działacze nie byli wykorzystywani do obrony interesów Watykanu i umacniania lokalnych

${ }^{66} \mathrm{~W}$ ruch byli zaangażowani buddyści z Japonii, Indii, Nepalu, Malezji, Demokratycznej Republiki Wietnamu, Wietnamu Południowego, ZSRR, Mongolii, Sri Lanki, Singapuru AAN, UdsW, sygn.. 136/13, Sprawozdanie z narady kierowników urzędów do spraw wyznań państw socjalistycznych, Warszawa 27 października 1975 r., k. 2.

${ }^{67}$ Tamże, k. 2.

${ }^{68}$ AAN, UdsW, sygn. 136/13, Sprawozdanie z narady kierowników urzędów do spraw wyznań państw socjalistycznych, Warszawa 27 października 1975 r., k. 3. 
kościołów"69. W dyskusji podkreślano problem Kościołów lokalnych w niektórych państwach, jako ośrodków antysocjalistycznych, mających duże wpływy na społeczeństwo. Zwracano uwagę na potrzebę przeciwstawiania się działalności tych Kościołów ${ }^{70}$. Sporo miejsca czasu poświecono omówieniu stosunków z Watykanem i ocenie okresowych dokonań $\mathrm{w}$ tym okresie ${ }^{71}$. Poszczególne delegacje dzieliły się doświadczeniami z przebiegu rozmów z Watykanem oraz ich efektami. Zwróciły uwagę, że niosą one niebezpieczeństwo ożywienia działalności Kościołów lokalnych. Podkreślały potrzebę demaskowania antykomunistycznej polityki Watykanu, niedopuszczania do rozszerzania jego oddziaływania na wierzących oraz ograniczanie jego wpływów na Kościoły katolickie w krajach socjalistycznych ${ }^{72}$. W odniesieniu do kształtowania się stosunków poszczególnych państw z Watykanem przyjęto następujące zasady:

zakres i charakter kontaktów z Watykanem określa każdy kraj w zależności od własnej specyfiki, tradycji i konkretnych problemów do rozwiązania; stosuje się przy tym elastyczne elementy taktyki; istnieje potrzeba dużej ostrożności w kontaktach, aby wyczuć granicę, poza którą kontakty te mogą przynieść jednostronne korzyści Watykanowi; uwzględniać należy, że głównym interesem Watykanu - także jako państwa - jest wypełnianie funkcji kierowniczej wobec Kościoła katolickiego w całym świecie i troska o jego umacnianie co jest programem opracowanym strategicznie i taktycznie ${ }^{73}$.

Poszczególne delegacje przeprowadziły ponadto rozmowy dwustronne na konkretne, interesujące obie strony tematy.

Na tym spotkaniu wszystkie strony potwierdziły potrzebę kontynuowania o charakterze instytucjonalnym ,wyznaniowych narad międzynarodowych" w celu koordynacji niektórych poczynań poszczególnych krajów w płaszczyźnie międzynarodowej. Przyjęły dokument zawierający główne tezy obrad oraz plan wspólnych działań.

Następna narada szefów urzędów wyznaniowych i pracowników komitetów centralnych partii komunistycznych i robotniczych z państw socjalistycznych odbyła się w Pradze w dniach od 19 do 21 stycznia 1982 r. Uczestniczyły w niej delegacje z Bułgarii, Kambodży, Kuby, Laosu, Węgier, Mongolii, NRD, Polski, Rumunii, ZSRR, Wietnamu, Czechosłowacji ${ }^{74}$.

Na naradzie poruszono kwestie związane z działalnością Kościołów, organizacji religijnych, działaczy kościelnych i wierzących na rzecz walki o pokój na świecie, rozbrojenie i przeciw niebezpieczeństwu wojny jądrowej. Uczestnicy narady jednomyślnie stwierdzili, że „w warunkach zaostrzenia napięcia międzynarodowego, gdy koła reakcyjne na czele z imperializmem amerykańskim dążą do

${ }^{69}$ Tamże, k.4.

${ }^{70}$ Tamże.

${ }^{71}$ Tamże.

${ }^{72}$ Tamże, k. 5.

${ }^{73}$ Tamże.

${ }^{74}$ AAN, UdsW, sygn. 128/131, Wystąpienie delegacji CSRS na naradzie przedstawicieli państwowych Urzędów do Spraw Wyznań i przedstawicieli KC partii w dniach 19-21.01.1982 r. w Pradze, Franciszka Cinoldr, k. 4-6. 
gorączkowych zbrojeń, nasilają wzrost potencjału wojennego NATO i prowadzą ludzkość do katastrofy jądrowej, niezmiernie ważne jest jeszcze bardziej wyraźne włączenie sił religijnych do walki przeciw niebezpieczeństwu jądrowemu”. Dlatego wszyscy uczestnicy narady pozytywnie ocenili inicjatywę zwołania ogólnoświatowej konferencji religijnej pod hasłem: „Działacze kościelni świata w walce przeciwko niebezpieczeństwu jądrowemu", którą zaplanowano na maju tego roku w Moskwie i wyrazili chęć aktywnego włączenia się jej przebieg. Nawiązując do współczesnej sytuacji międzynarodowej podjęli decyzję o zwiększeniu nacisków na działaczy kościelnych z państw socjalistycznych, by bardziej intensyfikowali starania $\mathrm{w}$ światowych międzynarodowych organizacjach religijnych „w celu aktywniejszego ich udziału $\mathrm{w}$ umocnieniu pokoju światowego i bardziej ofensywnego występowanie przeciwko niebezpieczeństwu katastrofy jądrowej"75. Zadeklarowali również wywierać większy nacisk na Kościoły, ich przedstawicieli oraz wszystkie kościelne organizacje, w celu popierania przez nie akcji pokojowych krajów socjalistycznych. Pozytywnie ocenili działalność Chrześcijańskiej Konferencji Pokojowej, Berlińskiej Konferencji Katolików Europy, Azjatyckiej Konferencji Buddyjskiej w Obronie Pokoju, Chrześcijańskiej Konferencji Pokojowej Ameryki Łacińskiej i Karaibów oraz zalecili dalsze wspieranie wszelkimi środkami ich działalność i mobilizowanie do współpracy z innymi organizacjami religijnymi w akcjach antywojennych.

Uczestnicy narady podkreślili potrzebę skuteczniejszego pogłębienia wzajemnej współpracy oraz wspólnego występowania działaczy kościelnych z państw socjalistycznych na arenie międzynarodowej w celu wspierania ,pokojowej polityki zagranicznej państw socjalistycznych". Zajęto się również pontyfikatem Jana Pawła $\mathrm{II}^{76}$. Analizując działalność tego polskiego papieża, zebrani towarzysze byli przekonani, że pod jego kierunkiem Watykan dąży do tego, aby Kościół katolicki w krajach socjalistycznych stał się opozycyjną siłą polityczną. Dlatego zalecono w kontaktach z Watykanem zachować czujność klasową, przeszkadzać w realizacji jego zamiarów antysocjalistycznych i równocześnie prowadzić z nim dialog o problemach obrony pokoju. W krytyce papieża, nie przeszkadzało wykorzystywania wypowiedzi papieskich na temat wojny i pokoju światowego do swoich celów. Punktem wyjścia do dyskusji była ocena polityki Watykanu w stosunku do krajów socjalistycznych, którą przyjęto na spotkaniu sekretarzy Komitetów Centralnych partii komunistycznych w lipcu 1979 r. w Berlinie. Wyrażano przekonanie, że Watykan „dąży do tego, aby pod przykrywką swojej ewangelicznej misji, stać się aktywną polityczną siłą we współczesnym świecie” i „zdecydowanie kontynuuje linię zwiększania aktywności Kościoła katolickiego próbując zmienić go w perspektywie w polityczną opozycję w stosunku do socjalistycznej rzeczywistości i w siłę przeciwdziałającą rozprzestrzenianiu się idei socjalizmu w krajach rozwijających się". Jako dowód podawano, że Jan Paweł II w swoich programowych wystąpieniach usilnie propaguje „chrześcijańską drogę” rozwoju

${ }^{75}$ AAN, UdsW, sygn. 128/131, Notatka z narady (dla pamięci), k.25-26.

${ }^{76}$ AAN, UdsW, sygn.. 128/131, Wystąpienie delegacji CSRS na naradzie przedstawicieli państwowych Urzędów do Spraw Wyznań i przedstawicieli KC partii w dniach 19-21.01.1982 r. w Pradze, Franciszka Cinoldr, k. 4-6. 
społeczeństwa czego dowodem miała być encyklika Laborem Exercens, w której starał się pogodzić ze sobą pracę i kapitał, dyskredytując jednocześnie marksizm-leninizm i realny socjalizm. Dostrzegli także nowe podejście papieża do kontaktów z krajami socjalistycznymi, w których strona kościelna porusza nie tylko sprawy religijne, ale też kwestie socjalne, polityczne czy też kulturalne i ma tendencje do wychodzenia poza ramy dyplomacji przez odwołanie się do szerokich mas. Komuniści dostrzegli, że Jan Paweł II dąży do przekształcenia Watykanu „w duchowe centrum świata i międzynarodowego arbitra we wszystkich istotnych konfliktowych problemach w stosunkach między krajami, a nawet światowymi systemami”. Ich zdaniem papież Jan Paweł II w zakres ewangelizacji włączył kwestię rozszerzenie praw katolików, wzmocnienie statusu Kościoła katolickiego i jego oddziaływania na życie społeczne, a na dodatek w swoim nauczaniu atakuje ateizm i naukowo-ateistyczny światopogląd, ukazując go jako „swoistą formę zniewolenia człowieka”. Podkreślano, że istotą jego strategii jest „okazywanie bezpośredniej pomocy imperialistycznym i antysocjalistycznym siłom w rozwijaniu ideologicznego i politycznego kontrataku przeciwko socjalizmowi”, a co gorsze ,proponowany przez niego krajom wschodu dialog pomoże w rozsadzeniu imperium radzieckiego od środka". Analizując politykę wschodnią Watykanu przedstawiciele Kremla stwierdzili, że pojawiła się z jego strony tendencja zaostrzenia kursu i „,wszelkimi sposobami podgrzewa on działalność elementów ekstremistycznych w Kościele katolickim. Jako przykład podali Litewską Socjalistyczną Republikę, w której papież kontynuuje inspirowanie bezprawnej działalności tzw. „komitetu obrony praw katolików”. Zarzucali mu aktywne popieranie unitów na Ukrainie i usprawiedliwianie ich nacjonalistycznych roszczeń, brak porozumienia $\mathrm{w}$ sprawie obsadzania stanowisk biskupich na Litwie lojalnymi księżmi oraz rozszerzenie przez Watykan zakresu audycji radiowych o treści antyradzieckie w językach litewskim i ukraińskim". W swojej ocenie nowej polityki wschodniej Watykanu konstatowali, że:

nie można nie wskazać na osobliwości taktyczne jej prowadzenia. W swoich działaniach nie stawia na konfrontację z krajami socjalistycznymi, ale na przenikanie do tych krajów. W tym celu Watykan dąży do podtrzymywania normalnych stosunków z krajami socjalistycznymi, podnosząc nawet ideę nawiązania stosunków dyplomatycznych. Prowadząc taką taktykę traktował np. Polskę jako teren doświadczalny $i$ aprobował rozwijającą się w ostatnich latach sytuację w tym kraju. I nie jest przypadkiem, że wprowadzony w Polsce stan wojenny wywołał niezadowolenie papieża. W swoim wystąpieniu z 30 grudnia zeszłego roku ostro osądził posunięcia polskiego rządu, scharakteryzował wprowadzenie stanu wojennego w PRL jako agresję prowadzącą do naruszenia zasadniczych praw człowieka i zażądał zmiany tego stanu. Jest to dalekie od przypadku, bowiem papież upatruje w normalizacji sytuacji $\mathrm{w}$ Polsce poważny uszczerbek dla jego planów. Pragnąłby, aby poprzedni kurs rozmydlania socjalizmu przedłużał się ${ }^{77}$.

${ }^{77}$ AAN, UdsW, sygn. 128/131, O aktywizacji działalności organizacji religijnych w walce o pokój, rozbrojenie, przeciwko zagrożeniu atomowemu, k. 19-22. 
Oceniając politykę Watykanu, jako antysocjalistyczną, zauważono jego realistyczne podejście do niektórych problemów międzynarodowych. Sądzono, że Watykan uświadamia sobie „niebezpieczeństwo wyścigu zbrojeń, nasilającego się szczególnie z przyjściem do władzy w USA administracji reaganowskiej, niebezpieczeństwa rozpętania przez militarystyczne koła USA i NATO wojny termojądrowej w Europie", co wymusza na Janie Pawle II wypowiadania się na tematy wojny i pokoju. Zasugerowano, aby w dalszym ciągu ,umiejętnie wspierać jego pokojowe akcje, wciągając Kościół katolicki do bardziej aktywnej walki przeciwko katastrofie atomowej”, czyli „popychać go do przechodzenia od słów na temat pokoju do konkretnych praktycznych działań, nie reklamując jego ostentacyjnej, pokojowej działalności”. Kończąc ten temat postanowiono nie dopuścić do realizacji przez Watykan ,,planów przenikania do krajów socjalistycznych z ich dalekosiężnym celem rozłożenia socjalizmu od środka". Zalecono uczestnikom spotkania „poważne przeanalizowanie doktryny socjalnej Watykanu, zawartej w encyklikach Jana Pawła II, zdemaskowanie jej demagogicznego, antynaukowego i antysocjalistycznego charakteru", gdyż wokół encyklik papieża jest dużo „hałasu wywoływanego przez uczonych burżuazyjnych w celu poparcia zawartych w nich koncepcji, a nasi uczeni na razie milczą" "78.

$\mathrm{Na}$ tym spotkaniu również po raz kolejny deklarowali chęć rozszerzenia współpracy „w duchu partyjnym pomiędzy urzędami państwowymi do spraw kościelnych państw socjalistycznych przez kontakty robocze na poziomie dwu lub wielostronne" i konieczność ,głębszego analizowania koncepcji społecznych i doktryn politycznych światowych centrów kościelnych"79. Zwrócono uwagę na wymianę wzajemnych doświadczeń ,z walki przeciwko wpływom religijnej ideologii i analizy, działań central Kościelnych”, do czego zobowiązały uchwały berlińskiego spotkania sekretarzy do spraw ideologicznych partii robotniczych i komunistycznych. W tym celu organizowano dodatkowo narady naukowców z krajów socjalistycznych, np. konferencje na temat politycznego klerykalizmu. Zastanawiano się także nad opracowaniem nowych metod i strategii działań wobec Watykanu ukierunkowanych na popieranie środowisk wewnątrzkościelnych kontestujących działania papieża i generowanie tam konfliktów wewnętrznych „wg. konkretnych możliwości poszczególnych krajów socjalistycznych”. Komuniści czechosłowaccy na przykład zadeklarowali „,czynić starania o zwiększanie poparcia dla Kościołów, działaczy kościelnych i różnych światowych instytucji religijnych w ich usiłowaniach w walce o pokój, odprężenie, rozbrojenie i zapobieganie jądrowemu kataklizmowi”, a jednocześnie deklarowali „,walkę z ideologią religijną i kościelnymi centrami, a zwłaszcza ze światowym katolicyzmem"80.

Omawiając kwestię polityki wobec Kościoła katolickiego zwrócono uwagę na działalność Konferencji Kościołów Europejskich, która we wcześniejszym okre-

${ }^{78}$ AAN, UdsW, sygn. 128/131, O aktywizacji działalności organizacji religijnych w walce o pokój, rozbrojenie, przeciwko zagrożeniu atomowemu, k. 19-22.

${ }^{79}$ AAN, UdsW, sygn. 128/131, Notatka z narady (dla pamięci), k. 26.

${ }^{80}$ AAN, UdsW, sygn. 128/131, Wystąpienie delegacji CSRS na naradzie przedstawicieli państwowych Urzędów do Spraw Wyznań i przedstawicieli KC partii w dniach 19-21.01.1982 r. w Pradze, Franciszka Cinoldr, k. 11. 
sie nie budziła zainteresowania. W związku z tym, że ta organizacja zdynamizowała swoją działalność zaproponowano podjęcie współpracy z nią przez przedstawicieli Rosyjskiej Cerkwi Prawosławnej, na podobnych zasadach jak współpraca Konferencji Kościołów Europejskich z Chrześcijańską Konferencją Pokojową. Zasugerowano wszystkim przedstawicielom organów wyznaniowych państw socjalistycznych, aby Konferencja Kościołów Europejskich pod naciskiem Kościołów krajów socjalistycznych bardziej stanowczo występowała przeciwko zagrożeniu atomowemu i popierała działaczy wyznaniowych, zaangażowanych w ruchy antywojenne na terenie Europy. Do tej akcji planowano wykorzystać także Światową Federację Luterańską i Światowy Związek Baptystyczny przez oddziaływanie luteranów i baptystów z krajów socjalistycznych. Zabrani przedstawiciele pionów wyznaniowych bardzo wysoko ocenili wysiłki podejmowane przez NRD i Mongolską Republikę Ludową na rzecz Berlińskiej Konferencji Katolików i Azjatyckiej Hinduskiej Konferencji w Obronie Pokoju, które jak podano odgrywały „ważną rolę w dziele mobilizacji sił wyznaniowych do walki o pokój”. Postanowiono zrobić wszystko, aby Berlińska Konferencja stała się najbardziej wpływową siłą w Europie, a Azjatycka Buddyjska Konferencja w Obronie Pokoju - w południowo-wschodniej Azji ${ }^{81}$.

Dwa lata później zorganizowano kolejną wspólną naradę. Odbyła się ona w miejscowości Dobris koło Pragi, w dniach 8-12 października 1984 r. Wzięli w niej udział przedstawiciele urzędów wyznaniowych z PRL, NRD, ZSRR, Czechosłowacji, Węgier, Rumuni, Bułgarii, Mongolii, Wietnamu, Laosu i Kuby ${ }^{82}$. Zasadniczo zajęto się dwoma zagadnieniami: Przygotowaniem VI kongresu Chrześcijańskiej Konferencji Pokojowej w Pradze w czerwcu 1985 r. oraz polityką Watykanu wobec krajów socjalistycznych ${ }^{83}$. Tym ostatnim zagadnieniem zajął się W.A. Kurojedow, odpowiedzialny za politykę wyznaniową w ZSRR. Pierwsza sprawa nie budziła problemów. Wszyscy byli za kongresem, który planowano na 2-9 lipca br. w Pradze, z udziałem także przedstawicieli Kościołów z krajów socjalistycznych ${ }^{84}$. Podjęto też kwestię ,szerokiej aktywizacji środowisk kościelnych i wyznaniowych na rzecz zachowania pokoju, przeciw niebezpieczeństwu wojny nuklearnej". Dlatego zdaniem uczestników przygotowania do Ogólnochrześci-

${ }^{81}$ AAN, UdsW, sygn. 128/131, O aktywizacji działalności organizacji religijnych w walce o pokój, rozbrojenie, przeciwko zagrożeniu atomowemu, k. 19-22.

${ }^{82}$ AAN, UdsW, sygn. 128/132, Notatka o rezultatach narady szefów urzędów do spraw wyznań krajów socjalistycznych, 8-12 października 1984 r., Dobriš k/Pragi CSRS, k. 1-2; UdsW, sygn.. 128/133, Notatka o rezultatach narady szefów urzędów do spraw wyznań krajów socjalistycznych, 8-12 października 1984 r., Dobriš k/Pragi CSRS, k. 1.

${ }^{83}$ AAN, UdsW, sygn. 128/132, Notatka o rezultatach narady szefów urzędów do spraw wyznań krajów socjalistycznych, 8-12 października 1984 r., Dobriš k/Pragi, k. 1-2; NAP, MK-SPLC, Seznam účastníku mezinárodní porady vedoucích představitelu Státních úřadupro vêci církevní socialistickych zemí, Dobřš, 8-12.10.1984, b.p.

${ }^{84}$ AAN, UdsW, sygn. 128/133, Pismo Vladimira Janka, Kierownika Sekretariatu do Spraw Kościelnych Rządu CSRS do Adama Łopatki Ministra-Kierownika Urzędu do Spraw Wyznań Polskiej Rzeczypospolitej Ludowej z dnia 14.02.1985 r., k. 66-68; Z Polski w kongresie będą uczestniczyć przedstawiciele PAX, ChSS, Polskiej Rady Ekumenicznej i Społecznego Towarzystwa Polskich Katolików, razem: 3-13 osób. 
jańskiego Zgromadzenia Pokoju nabrały szczególnego politycznego znaczenia. Zasugerowano wyjście naprzeciw wszystkim kościelnym i wyznaniowym środowiskom, które ,Zz różnych ideologicznych pozycji, gotowe są do obrony pokoju, do rozbrojenia, przeciwne są przygotowaniom do wojny, wyścigowi zbrojeń, gotowe poprzeć walkę narodów o wolność i sprawiedliwość, przeciw rasizmowi i apartheidowi”. Podkreślono, że ważnym ,zadaniem ChKP, jest też pomoc tym wszystkim, którzy pozostają pod wpływem różnych dezinformacji i potrzebują właściwej orientacji. A przy tym, ChKP musi zachować własną tożsamość awangardy pokojowych sił kościelnych świata”. Uczestnicy spotkania zadeklarowali pomoc w przygotowaniach do tego Zgromadzenia Pokoju oraz podjęcie działań na rzecz zwiększenia wewnętrznej jedności ChKP i efektywności jej poczynań.

W sprawie polityki Watykanu wobec krajów socjalistycznych zaaprobowano główne myśli referatu W.A. Kurojedowa. Bardziej zróżnicowanie na temat tego referatu wypowiedzieli się przedstawiciele Polski, Węgier i Czechosłowacji. Ostrzej od referenta wypowiedział się przedstawiciel CSRS ${ }^{85}$. W referacie $O$ środkach przeciwdziałania antyradzieckiej $i$ antysocjalistycznej działalności Watykanu w obecnym czasie, przedstawiciel Kremla wskazał, że papież Jan Paweł II zwalcza ideologię ateistyczną i lansuje koncepcję „,chrześcijańskiego zjednoczenia Europy”, ponieważ chce - jego zdaniem - utworzyć „międzynarodówkę religii”, w której nie będzie miejsca ani dla marksizmu-leninizmu, ani dla materializmu zachodniego. Również na tym spotkaniu podkreślono, że „Watykan i papież stanowią niebezpieczną siłę, już otwarcie zmierzającą do erozji socjalizmu". Skarżono się, że jeszcze w sposób wyraźnie niewystarczający prowadzi się działania zmierzające „,do zdemaskowania wrogiej działalności Watykanu oraz na małe angażowanie się instytucji naukowych, organizacji literatów, filmu i środków masowego przekazu" w zwalczanie wpływów watykańskich w społeczeństwach socjalistycznych. Dlatego strona sowiecka pochwaliła się, że z powodu wzrostu „,intensywności katolickiej propagandy antyradzieckiej oraz dywersyjnych akcji Watykanu” w ZSRR podjęto „działania w celu skuteczniejszego przeciwstawienia, się ideologicznym dywersjom reakcyjnego katolicyzmu oraz zdemaskowania prób ośrodków zagranicznych" ${ }^{86}$. Towarzysze sowieccy posądzili Watykan o inspirowanie do większej aktywności Kościół katolicki na Litwie i popieranie „ekstremistów religijnych”. Podkreślili, że „kierownictwo światowym ośrodkiem katolicyzmu objął człowiek mocny, o silnej woli, zaciekły antykomunista, dobrze obeznany z działalnością Kościoła w krajach socjalistycznych i otwarcie stawiający sobie za cel umocnienie pozycji Kościoła katolickiego i przekształcenie go w opozycję polityczną, zwalczającą ustrój socjalistyczny. Papież coraz otwarciej wyraża swą wrogość do socjalizmu" ${ }^{87}$. Tezy radzieckiego przedstawiciela podzielali towarzysze z innych krajów. Oni również podkreślali, że w ostatnim okresie daje o sobie znać ,antysocjalistyczna istota polityki prawicowych kół Watykanu,

${ }^{85}$ AAN, UdsW, sygn. 128/132, Notatka o rezultatach narady szefów urzędów do spraw wyznań krajów socjalistycznych, 8-12 października 1984 r., Dobriš k/Pragi, k. 1-2.

${ }^{86} \mathrm{AAN}, \mathrm{UdsW}$, sygn. 128/133, O środkach przeciwdziałania antyradzieckiej i antysocjalistycznej działalności Watykanu w obecnym czasie, k. 153.

${ }^{87}$ Tamże, k. 148. 
które coraz aktywniej przyłączają się do ogłoszonego przez Reagana pochodu krzyżowego przeciw komunizmowi”. Oskarżali Watykan o inspirowanie prowokacji i dążenie do utworzenia $\mathrm{z}$ wierzących katolików krajów socjalistycznych legalnej opozycji oraz o chęć uczynienia z Kościoła katolickiego siły politycznej wrogiej socjalizmowi. W ich opinii Watykan łączył się z imperialistyczną reakcją USA $\mathrm{i}$ innych państw NATO w usiłowaniach przytłumienia woli narodów o wyzwolenie polityczne, społeczne i duchowe”. Dostrzeżono, że „Watykan otwarcie występuje przeciw udziałowi katolików w ruchach narodowowyzwoleńczych. Potępił postępowych katolickich działaczy z Ameryki Łacińskiej uczestników walki z imperializmem. Papież występuje wprawdzie jako obrońca spokoju, ale faktycznie zabrania katolikom uczestniczyć w ruchach przeciw wojnie przez co wspomaga podżegaczy wojny jądrowej”. Uczestnicy narady doszli wniosku, że

aktualne warunki narzucają potrzebę nasilenia wspólnej akcji wymierzonej przeciwko podejmowanym przez reakcyjny katolicyzm usiłowaniom wykorzystania religii w celach antykomunistycznych i antysocjalistycznych, a także wspólnych działań w obronie ruchu antywojennego i wyzwoleńczego.

Podkreślili również, że:

w aktualnych warunkach rzeczą niezwykle ważną jest pogłębianie wzajemnych kontaktów i wzajemnej wymiany informacji pomiędzy krajami socjalistycznymi, jak również, koordynacja poczynań wymierzonych przeciwko siłom antysocjalistycznym i w obronie pokojowego zaangażowania Kościołów, Zadeklarowali wsparcie krajów socjalistycznych dla rozwoju kontaktów między Kościołami i umacnianie pozytywnych wpływów tych Kościołów na sytuację światową.

Oprócz wymiany informacji na temat działalności Watykanu przeprowadzono dyskusję na temat ruchów wolnościowych i antywojennych. Ponadto poszczególne delegacje poinformowały o problemach kościelno-politycznych, uznanych przez nie za istotne ze społecznego punktu widzenia. Uczestnicy spotkania stwierdzili, że poważne współczesne zaostrzenie stosunków międzynarodowych rzutuje na działalność Kościołów ${ }^{88}$. Zasugerowano, wciągnięcie organizacji religijnych krajów socjalistycznych do zablokowania „reakcyjnych akcji Watykanu i pozyskania katolików do walki przeciw groźbie wojny atomowej”. Wspólnie stwierdzono, że zaostrzenie się sytuacji międzynarodowej przejawia się także w działalności Kościołów, zwłaszcza w wyniku dążenia wrogich, antysocjalistycznych sił do zakłócenia pokojowego ruchu kościołów i do wyeliminowania jego dotychczasowych sukcesó $w^{89}$. W podsumowaniu narady uczestnicy doszli do wspólnego wniosku, że „w dziedzinie polityki wyznaniowej rok 1985 r. będzie rokiem szczególnym, zaś stojące przed nami zadania można będzie pomyślnie rozwiązać tylko we wzajemnej współpracy"90.

${ }^{88}$ AAN, UdsW, sygn. 128/132, Zapis protokolarny, k. 6-9.

${ }^{89}$ AAN, UdsW, sygn. 128/133, Pismo Vladimira Janka Kierownika Sekretariatu do Spraw Kościelnych Rządu CSRS do Adama Łopatki Ministra-Kierownika Urzędu do Spraw Wyznań Polskiej Rzeczypospolitej Ludowej z dnia 14.02.1985 r., k. 66-68.

${ }^{90}$ AAN, UdsW, sygn. 128/133, Pismo Vladimira Janka Kierownika Sekretariatu do Spraw Kościelnych Rządu CSRS do Adama Łopatki Ministra-Kierownika Urzędu do Spraw Wyznań Polskiej Rzeczypospolitej Ludowej z dnia 14.02.1985 r., k. 66-68. 
Wspólne narady urzędników wyznaniowych z krajów bloku wschodniego stanowiły płaszczyznę wymiany informacji, doświadczeń, koordynacji i zharmonizowania głównych kierunkowych działań oraz pomoc w tworzeniu kościelnych i wyznaniowych struktur organizacyjnych ukierunkowywanych na realizację polityki zgodnej z doktryną komunistyczną, wspólne uzgadnianie przedstawicieli Kościołów, związków wyznaniowych i organizacji wyznaniowych z bloku wschodniego do władz w międzynarodowych organizacjach religijnych, jak np. Berlińska Konferencja Katolików Europy i Chrześcijańska Konferencja Pokojowa, Światowa Rada Kościołów oraz przedstawicieli do doraźnych akcji, a także omawianie i ustalanie wspólnej linii postępowania wobec Watykanu. Omawiano zasadnicze problemy polityki wyznaniowej, ze szczególnym uwzględnieniem analizy celów politycznych i taktyki działania najważniejszych Kościołów i organizacji wyznaniowych. Urzędnicy wyznaniowi poszczególnych krajów informowali pozostałych uczestników konferencji o zasadniczych problemach sytuacji w dziedzinie stosunków państwo - Kościół u siebie. Spotkanie te przyczyniły się do pogłębienia współpracy pomiędzy krajami socjalistycznymi w dziedzinie polityki wyznaniowej. Wynikały ona $\mathrm{z}$ potrzeby wzajemnej współpracy w dziedzinie kościelno-politycznej, szczególnie od lat 60. XX w., gdy nastąpiła zmiana polityki Watykanu wobec bloku wschodniego oraz zwiększonej aktywności innych Kościołów.

\section{BIBLIOGRAFIA}

\section{Źródła}

Archiwum Akt Nowych (AAN)

sygn.: 133/3; 136/2; 136/4; 136/7; 136/9; 136/10; sygn.136/13, 127/82; 144/15; 128/131; $128 / 132 ; 128 / 133$.

Narodní Archiv v Praze (NAP)

sygn. 47 ;

MK-SPLC, Přehled mezístátních jednani v létech 1961-1968.

\section{Opracowania}

Dmowski M., Organizacja Układu Warszawskiego 1955-1980. LRB, CSRS, NRD, PRL, SRR, WRL, ZSRR. Dokumenty i materiaty, Warszawa 1981.

Kaczmarek K., Prawda i ktamstwo. Prymas Wegier Józef Mindszenty, Poznań-Warszawa 2002.

Parzymies S., Stosunki międzynarodowe w Europie 1945-2009, Warszawa 2009.

Madajczyk P., Dyplomacja polska w latach sześćdziesiatych, w: Historia dyplomacji polskiej, t. VI: 1944/45-1989, red. W. Materski, W. Michowicz, Warszawa 2010, s. 589591 . 
Skobelski E., Polityka PRL wobec państw socjalistycznych w latach 1956-1970. Wspótpraca-napięcia-konflikty, Poznań 2010.

Zając J., Zięba R., Polska w stosunkach międzynarodowych 1945-1989, Toruń 2005, s. 11-12;

\title{
WSPÓŁPRACA WYDZIALÓW WYZNANIOWYCH PAŃSTW BLOKU WSCHODNIEGO (WSPÓLNE NARADY)
}

\begin{abstract}
Streszczenie
Państwa socjalistyczne od początku lat $60 . \mathrm{XX}$ wieku, aż do końca istnienia bloku wschodniego, podjęły współpracę w kwestiach dotyczących polityki wyznaniowej. Wyrazem tej współpracy były organizowane wspólne narady urzędników wyznaniowych z krajów bloku wschodniego. Stanowiły płaszczyznę wymiany informacji, doświadczeń, koordynacji i zharmonizowania głównych kierunkowych działań oraz pomoc w tworzeniu wyznaniowych struktur organizacyjnych ukierunkowywanych na realizację polityki zgodnej z doktryną komunistyczną, wspólne uzgadnianie przedstawicieli Kościołów, związków wyznaniowych i organizacji wyznaniowych z bloku wschodniego do władz w międzynarodowych organizacjach religijnych, jak np. Berlińska Konferencja Katolików Europy i Chrześcijańska Konferencja Pokojowa, Światowa Rada Kościołów, a także omawianie i ustalanie wspólnej linii postępowania wobec Watykanu. Na tych naradach omawiano zasadnicze problemy polityki wyznaniowej, ze szczególnym uwzględnieniem analizy celów politycznych i taktyki działania najważniejszych Kościołów i organizacji wyznaniowych. Urzędnicy wyznaniowi poszczególnych krajów informowali pozostałych uczestników konferencji o zasadniczych problemach sytuacji w dziedzinie stosunków państwo-kościół u siebie. Spotkanie te przyczyniły się do pogłębienia współpracy pomiędzy krajami socjalistycznymi w dziedzinie polityki wyznaniowej. Wynikały ona z potrzeby wzajemnej współpracy w dziedzinie kościelno-politycznej, szczególnie od lat 60 XX wieku, gdy nastąpiła zmiana polityki Watykanu wobec bloku wschodniego oraz zwiększonej aktywności innych Kościołów.
\end{abstract}

Słowa kluczowe: Watykan; komunizm; polityka wyznaniowa; Chrześcijańska Konferencja Pokojowa; państwa socjalistyczne 


\title{
COOPERATION OF THE RELIGIOUS DEPARTMENTS OF THE EASTER BLOC COUNTRIES (MEETINGS)
}

\begin{abstract}
Summary
From the early 1960s to the end of the existence of the Eastern Bloc, the socialist countries began cooperation on a religious policy. As a result, officials from the countries of the Eastern Bloc who dealt with religious matters held meetings to discuss the issues mentioned above. The meetings provided a great opportunity for the exchange of information, experience and coordination, and for the harmonization of the main trends in the activity of these countries; as well as assistance in creating religious organizational structures aimed at implementing a religious policy which would be in line with the communist doctrine. In addition, they met to discuss the course of action towards the Vatican, and to designate the representatives of Churches, religious associations and organizations from the Eastern Bloc for international religious organizations such as the Berlin Conference of European Catholics, the Christian Peace Conference and the World Council of Churches. These meetings were also an occasion for discussing major problems of a religious policy, with particular emphasis on the analysis of political goals and the tactics of the most important Churches and religious organizations. Officials dealing with religious matters informed the other members of the conference about major problems in the relations between the church and state in their countries. These meetings contributed to deepening cooperation between socialist countries on a religious policy. These consultations were held due to the necessity of mutual cooperation on the issues relating to the Church and politics, especially from the 1960s onwards, when the Vatican changed its policy towards the Eastern Bloc and when other Churches became more active.
\end{abstract}

Keywords: the Vatican; communism; officials dealing with religious matters; cooperation; the Christian Peace Conference; socialist countries 